\title{
Tinjauan Perkembangan dan Pertumbuhan Perbankan Syariah di Indonesia
}

\author{
Dedi Suhendro \\ AMIK Tunas Bangsa Pematangsiantar \\ Dedi.su@amiktunasbangsa.ac.id
}

\begin{abstract}
The largest population of Islam in the world is an Indonesian country where the amouth of Muslim population reaches 204 million inhabitants. The amouth of Islam that is classified as many in Indonesia, has a potential to trigger the development and growth of sharia banks. Government's attention and support for sharia banking is strengthened by the policy with the issuance of sharia banking law. PT Bank Mualat Indonesia is the first syariah bank in Indonesia which was established and operated in 1992 then followed by other sharia bank. PT Bank Muamalat Indonesia was born from the work of the banking team of the Majelis Ulama Indonesia (MUI), which on November 1, 1991 signed the deed of establishment of PT Bank Muamalat Indonesia, collected the purchase of shares of Rp.84 billion. The established sharia bank is a financial services banking institution operating on the basis of Islamic ethics and value systems, especially those free of interest (riba), free from speculative non-productive activities such as gambling (maysir), free from unclear and dubious matters (gharar), based on justice principles, and only finance halal business activities. The institutional sector from 2007 to 2017 when viewed from the BUS_Islamic Commercial Bank) has increased although the increase is not too high, while the USS (Islamic Business Unit of a Conventional Bank) has fluctuated, the a mouth of BPRS (Islamic Rural Bank) has increased very well, growth the a mouth of sharia banking office network also fluctuated. The development and growth of total assets, DPK (Depositor Funds), and the amount of PYD (Financing) has always increased from 2007 to 2017. So that Islamic banks become a good banking model and is ideal in advancing the nation's economy.
\end{abstract}

Keywords: Islamic Banking Statistics, Development, Growth, Indonesia

\section{Pendahuluan}

Aktivitas dalam bidang seni perekonomian sudah ada sejak zaman Rasulullah SAW dan banyak permasalahan bidang ekonomi yang dihadapi oleh manusia, sehingga banyak pakar ekonomi berpikir bagaimana merubah ilmu ekonomi menjadi ilmu ekonomi seperti sekarang ini. Cabang ilmu ekonomi yang terus berkembang sesuai dengan perkembangan peradaban manusia adalah dalam bidang perbankan. Ekonomi konvensional memang masih jauh lebih unggul dibandingkan dengan ekonomi syariah tetapi seiring dengan kemajuan zaman banyak didirikan lembaga syariah yang semakin berkembang dan tumbuh. Dalam 
penelitian yang ditulis oleh Marimin et al (2015) menyatakan bahwa para pakar ekonomi memperkirakan dan memprediksikan yang mana ekonomi syariah akan mengalami perkembangan dan pertumbuhan yang maju dari ekonomi konvensional

Kehidupan pada zaman Rasulullah SAW belum adanya institusi seperti perbankan namun dalam aktifitas perdagangan dan perekonomiannya sudah memberikan berpedoman untuk menerapkan prinsip, hukum serta filosofi kaidah ajaran Islam. Cara yang dilakukan dengan mengidentifikasi prinsip, hukum dan filosofi dasar dalam ajaran Islam dibidang ekonomi, dan kemudian mengidentifkasi semua hal yang dilarang hal ini dilakukan untuk menghadapi masalah-masalah muamalah kontemporer.

Karena untuk dapat melakukan suatu kreativitas dan inovasi (ijtihad) dalam memecahkan masalah dan persoalan muamalah kontemporer termasuk dalam masalah dan persoalan perbankan maka yang harus dilakukan adalah mengidentifikasi semua yang dilarang sesuai dengan prinsip, hukum dan filosofi ajaran islam dibidang ekonomi (Marimin et al., 2015).

Menurut Nofinawati (2015) dalam penelitiannya menyatakan bahwa berdasarkan sejarah perekonomian Islam, dimana tradisi umat Islam sejak zaman Rasulullah SAW untuk masalah pembiayaan harus dilakukan dengan akad dan harus sesuai dengan syariah yang berlaku. Seperti praktik pengiriman uang, penerimaan dalam penitipan harta benda serta meminjam uang untuk hal bisnis dan konsumsi. Sehingga dapat disimpulkan bahwa tugas utama perbankan konvensional menerima simpanan dana atau deposit, penyaluran dana kepada masyarakat, serta pengiriman dana yang mana kegiatan ini tidak bisa terlepas dan terpisahkan dari kehidupan umat Islam.

Dalam kehidupan Rasulullah SAW dan Siti Khadijah pernah mempraktikkan sistem akad mudharabah, Siti Khadijah bertindak sebagai shahibul maal (pemilik modal) dan Rasulullah SAW bertindak sebagai mudharib (pengelola dana) yang mana mudharabah adalah suatu bentuk kerjasama antara pemilik modal/dana dengan pengelola yang disertai suatu perjanjian. Dana yang sudah terhimpun kemudian dikelola oleh Rasulullah SAW kedalam bentuk usaha perdagangan. Setelah Rasulullah SAW mendapatkan hasil dari usaha perdagangan nya, maka Rasulullah SAW membagi hasil kepada Siti Khadijah sesuai dengan kesepakatan pada saat akad. Sehingga dapat dipahami bahwa sebenarnya lembaga 
perbankan belum ada pada zaman Rasullah SAW, namun kenyataannya praktik perbankan telah menjadi tradisi umat Islam (Nofinawati, 2015).

\section{Perkembangan Dan Pertumbuhan Perbankan Syariah}

Bank salah satu usaha yang kegiatannya menghimpun dana dari masyarakat seperti bentuk simpanan kemudian meyalurkan kembali kepada masyarakat dalam bentuk pemberian kredit (Suhendro, 2018).

Dalam praktiknya bank syariah atau dinegara lain disebut Islamic Bank melaksanakan kegiatan sesuai dengan prinsip-prinsip syariah, yaitu menerapkan sistem perjanjian antara bank syariah dengan pihak lain yang menyangkut penyimpanan dana atau pembiayaan sesuai dengan hukum islam sehingga sangat berbeda dengan bank konvensional.

Perbedaaan yang mendasar antara bank konvensional dengan bank syariah, seperti diketahui bahwa bank konvensional menjalankan sistem bunga yang mana sistem bunga mengandung unsur dan prinsip riba, dalam sistem bunga adanya ketidakadilan disebabkan pihak bank konvensional (pemilik dana) memberikan kewajiban kepada peminjam untuk membayar lebih dari dana yang dipinjamnya tanpa melihat apakah peminjam mendapat keuntungan atau mengalami kerugian. Sehingga sistem bunga dilarang dalam ajaran agama islam. Sedangkan bank syariah berlandaskan pada sistem bagi hasil yang menerapkan prinsip dimana ketika peminjam dan pihak bank syariah (pemilik dana) berbagi dalam keuntungan dan risiko kerugian dengan pembagian sesuai dengan kesepakatan. Ditinjau dari perspektif bidang ekonomi, bank syariah merupakan sebuah lembaga keuangan yang menyalurkan dana investasi kepada publik secara optimal dengan larangan riba dan kewajiban zakat yang bersifat produktif serta dijalankan sesuai prinsip, nilai, etika dan moral ajaran Islam (Diana Yumanita, 2010).

Menurut Nofinawati (2015) sistem perbankan yang menggunakan sistem bagi hasil telah ada sejak lama, yang diawali dengan banyaknya pemikiranpemikiran kaum muslim dalam tulisan mereka tentang adanya bank syariah, misalnya tulisan-tulisan Muhammad Hamidullah yang ditulis pada 1944, 1955, 1957, dan 1962, bisa dikategorikan sebagai gagasan terdahulu mengenai perbankan Islam. Anwar Qureshi pada tahun 1946, Naiem Siddiqi pada tahun 1948, dan Mahmud Ahmad pada tahun 1952. Kemudian uraian yang lebih terperinci tentang gagasan itu ditulis oleh Mawdudi pada tahun 1961. 
Catatan sejarah menceritakan bahwa pada tahun 1940-an di Malaysia dan Pakistan perkembangan terhadap bank syariah dalam upaya terhadap pengelolaan dana untuk para jemaah haji dengan prinsip non-konvensional (Nofinawati, 2015). Tetapi sejarah lain menceritakan pada tahun 1963 pertama kali bank syariah adalah Mit Ghamr Lokal Saving Bank didirikan oleh Dr. Ahmad el-Najar di kota kecil, Mesir sebagai pilot project dalam bentuk bank tabungan pedesaan. Pada tahun 1965 didirikan di Pakistan dalam bentuk bank koperasi (Sari et al., 2013). Gerakan bank syariah mulai hidup pada pertengahan tahun 1970-an, seperti berdirinya Islamic Development Bank pada tahun 1975 sebagai lembaga keuangan internasional Islam multilateral, hal inilah yang menggerakkan didirikannya bank syariah di negara lain seperti Dubai Islamic Bank di Dubai pada tahun 1975, Kuwait Finance House di Kuwait tahun 1977 dan Faisal Islamic Bank di Mesir dan Sudan pada tahun 1977. Jumlah bank dan lembaga keuangan syariah mencapai lebih dari 200 yang beroperasi di 70 negara baik negara muslim dan negara non-muslim dan total portofolionya berkisar \$200 milyar (Diana Yumanita, 2010).

Sehingga pada tanggal 21 s/d 27 April 1969 diselenggarakannya konferensi tingkat Internasional yang diadakan di Kuala Lumpur, Malaysia tentang gagasan berdirinya bank syariah, yang diikuti 19 negara. Hasil konferensi tingkat Internasional tersebut merumuskan:

1. Tiap keuntungan haruslah tunduk kepada hukum laba dan rugi, jika tidak ia termasuk riba dan riba itu sedikit atau banyak hukumnya haram.

2. Diusulkan supaya dibentuk suatu bank syariah yang bersih dari sistem riba dalam waktu secepat mungkin.

3. Sementara menunggu berdirinya bank syariah, bank-bank yang menerapkan bunga diperbolehkan beroperasi. Namun jika benar-benar dalam keadaan darurat.

Pembentukan bank syariah semula memang banyak diragukan, sebab:

1. Banyak yang beranggapan bahwa sistem perbankan bebas bunga (interest free) adalah suatu yang tak mungkin dan tidak lazim.

2. Adanya pertanyaan tentang bagaimana bank akan membiayai operasinya. Tetapi di lain pihak, bank Islam adalah satu alternative sistem ekonomi Islam (Nofinawati, 2015). 
Selain diselenggarakan nya konferensi tingkat Internasional yang diadakan di Kuala Lumpur, Malaysia. Untuk lebih mempermudah berkembangnya bank syariah di negara-negara muslim perlu ada usaha bersama di antara Negara muslim maka pada Desember 1970, dalam Sidang Menteri Luar Negeri negaranegara Organisasi Konferensi Islam (OKI) di Karachi, Pakistan, delegasi dari negara Mesir mengajukan proposal untuk didirikannya bank syariah untuk Perdagangan dan Pembangunan (International Islamic Bank for Trade and Development) dan proposal pendirian Federasi Bank Islam (Federation of Islamic Bank) sehingga dikaji para ahli dari 18 negara Islam.

Pada Maret 1973 di Benghazi, Libya kembali usulan tersebut diagendakan oleh menteri-menteri luar negeri dalam agenda Organisasi Konferensi Islam (OKI) dimana sidang tersebut merumuskan supaya Organisasi Konferensi Islam (OKI) memiliki suatu lembaga yang menangani dalam bidang permasalahan keuangan dan ekonomi. Sedangkan pada bulan Juli 1973, kembali membicarakan pendirian bank syariah yang diwakili negara-negara Islam penghasil minyak bertemu di Jeddah, Arab Saudi. Pendirian bank tersebut, berupa anggaran dasar dan anggaran rumah tangga. Pada Mei 1974 di Jeddah pertemuan kedua kali nya untuk sidang Menteri Keuangan Organisasi Konferensi Islam (OKI) dan disetujui untuk pendirian Bank Pembangunan Islam atau Islamic Development Bank (IDB) dengan modal 12 miliar dinar atau ekuivalen 2 miliar SDR (special drawing right) IMF (International Monetary Fund). Dengan berdirinya Islamic Development Bank (IDB) memotivasi negara-negara Islam dunia untuk mendirikan lembaga keuangan syariah. Akhir periode 1970-an dan awal 1980-an, lembaga keuangan syariah didirikan di Mesir, Sudan, Pakistan, Iran, Malaysia, serta Turki termasuk Indonesia pada periode 1990-an. Ada juga negara-negara non-muslim yang mendirikan bank Islam, seperti Swiss, Luxemburg, Inggris, Bahamas (Benon) dan Denmark (Nofinawati, 2015).

Dalam penelitian Nofinawati (2015) menyatakan bahwa seiring dengan berkembang pesat bank syariah menyebabkan bank konvensional tertarik untuk menawarkan produk bank syariah, hal ini tercermin dari tidakan bank konvensional untuk membuka sistem di masing-masing bank dalam menawarkan produk-produk bank syariah suatu contoh di Malaysia adanya produk "Islamic windows", di Mesir dengan produk "the Islamic transactions", bank perdagangan Arab Saudi dengan produk "the Islamic services" dan pada tahun 1996 Citibank di 
Bahrain mendirikan Citi Islamic Investment yang merupakan wholly-owned subsidiary.

\section{Perbankan Syariah Di Indonesia}

Perkembangan perekonomian nasional yang dihadapi dunia usaha saat ini sangat cepat dan dinamis (Suhendro, 2016). Awal mulanya perbankan hanya ada di Eropa yang penyebarannya sampai ke Asia Barat, karena perluasan dan perkembangan dari daerah jajahan maka sistem perbankan banyak diterapkan pada negara jajahannya. Sama halnya dengan negara yang pernah dijajah oleh negara Belanda, sehingga negara Belanda mendirikan bank seperti De Post Paar Bank, De Javasche Bank serta masih ada lagi bank-bank milik bangsa Indonesia sendiri. Perbankan Indonesia sudah menunjukkan kemajuan pada zaman kemerdekaan baik bank yang didirikan oleh pemerintah maupun bank milik swasta (Nofinawati, 2015).

Sudah lama masyarakat Islam Indonesia memiliki keinginan untuk didikannya bank syariah dengan syariat Islam yang di prakarsai tokoh ulama, para cendikiawan dan pakar ekonomi Islam. Hasrat dan keinginan untuk mendirikan konsep ekonomi Islam sebenarnya sudah mulai dipikirkan oleh para tokoh ulama di tahun 1930-an. Pada masa kepemimpinan K.H Mansur sebagai ketua PP Muhammdiyah pada tahun 1937 sampai tahun 1944 beliau menginginkan serta menyerukan suatu pendapat terhadap haramnya produk bank konvensional bagi masyarakat dan umat Islam. Pada saat itu beliau mengemukakan pendapat dan gagasan untuk mendirikan bank Islam di Indonesia (Fasa, 2013).

Penelitian Fasa (2013) menyatakan bahwa peran pemerintah, para tokoh ulama, cendikiawan dan pakar ekonomi Islam sangat penting. Seperti peran mantan presiden Suharto, B.J. Habibie sebagai ketua umum ICMI atau Rahmat Saleh sebagai mantan Gubernur Bank Indonesia pada saat itu. Tokoh penting inilah yang mampu untuk menarik para investor, BUMN dan yayasan.

Menurut Alamsyah (2012) Indonesia merupakan negara dengan penduduk Islam terbesar dunia, selayaknya menjadi pelopor dalam perkembangan dan pertumbuhan perbankan syariah. Indonesia memiliki ruang yang sangat besar terhadap perbankan syariah agar menjadi global player, dikarenakan:

1. Dimana jumlah penduduk Islam yang besar merupakan suatu potensi dari nasabah dalam bidang keuangan syariah. 
2. Adanya prospek perekonomian yang berkembang, hal ini terlihat dari pertumbuhan perekonomian Indonesia kisaran 6\% sampai 6,5\% dalam rentang ekonomi yang solid.

3. Meningkatnya sovereign credit rating Indonesia menjadi investment grade dalam hal ini berpengaruh terhadap minat para investor untuk berinvestasi didalam negeri termasuk perbankan syariah.

4. Indonesia yang memiliki kekayaan alam sehingga dapat dijadikan sebagai underlying terhadap transaksi keuangan syariah (Syukron, 2013).

Sementara di Indonesia, pada awal tahun 1990-an bank syariah berdiri yang dikenal dengan nama Bank Muamalat Indonesia. Dalam praktiknya bank syariah mampu dalam memenuhi kebutuhan di masyarakat Indonesia dengan pelayanan jasa perbankan sesuai dengan prinsip syariah agama Islam, hal-hal yang berkaitan dengan pelarangan terhadap riba, ketidakjelasan, penyaluran dalam pembiayaan/investasi pada kegiatan usaha yang etis halal secara syariah, pelanggaran prinsip keadilan dalam bertransaksi serta kegiatan yang bersifat spekulatif yang non-produktif (perjudian).

Perkembangan bank syariah secara pesat semenjak era reformasi pada akhir tahun 1990-an, setelah pemerintah dan Bank Indonesia memberikan kebijakan dalam mengembangkan bank syariah, dengan dikeluarkan nya undangundang perbankan dengan UU No. 10 tahun 31998 yang mana kebijakan tersebut tidak hanya tentang perluasan operasi bank-bank syariah dan jumlah kantor untuk meningkatkan sisi penawaran, tetapi juga menyangkut pengembangan pemahaman dan kesadaran masyarakat untuk meningkatkan sisi permintaan.

Perkembangan bank syariah dalam sejarah Indonesia semenjak dikeluarkannya ketentuan dari Bank Indonesia tentang pemberian izin untuk membuka bank syariah atau memberikan izin terhadap bank konvensional untuk mendirikan Unit Usaha Syariah (UUS). Bank syariah merupakan lembaga perbankan penyedia jasa keuangan yang beroperasi berdasarkan etika dan sistem nilai Islam, khususnya yang bebas dari bunga (riba), bebas dari kegiatan spekulatif yang nonproduktif seperti perjudian (maysir), bebas dari hal-hal yang tidak jelas dan meragukan (gharar), berprinsip keadilan, dan hanya membiayai kegiatan usaha yang halal (Munawir, 2005).

Bank Syariah sering dipersamakan dengan bank tanpa bunga yang mulai banyak berkembang ibaratkan jamur dimusim hujan. Selain menghindari bunga, 
juga secara aktif turut serta dalam berpartisipasi untuk mencapai sasaran dan tujuan dari ekonomi Islam yang berorientasi pada kesejahteraan sosial. Prinsipprinsip Dasar Perbankan Syariah Dalam operasinya, bank Syariah mengikuti aturan-aturan dan norma-norma Islam, seperti yang disebutkan dalam pengertian di atas, yaitu:

1. Bebas dari bunga (riba)

2. Bebas dari kegiatan spekulatif yang non produktif seperti perjudian (maysir)

3. Bebas dari hal-hal yang tidak jelas dan meragukan (gharar)

4. Bebas dari hal-hal yang rusak atau tidak sah (bathil) dan

5. Hanya membiayai kegiatan usaha yang halal. Secara singkat empat prinsip pertama biasa disebut anti MAGHRIB (maysir, gharar, riba, dan bathil) (Diana Yumanita, 2010).

Bank Indonesia selaku regulator memberikan perhatian dengan sungguhsungguh dan serius dalam perkembangan perbankan syariah. Dengan semangat yang kuat serta dilandasi adanya keyakinan bahwa bank syariah akan memberi dan membawa maslahat untuk pemerataan dan meningkatkan perekonomian rakyat.

1. Bank syariah lebih cenderung dengan sektor riil sebab produk-produk yang ditawarkan dalam hal pembiayaan selalu menggunakan underlying sehingga lebih nyata dalam sektor riil dalam pertumbuhan ekonomi.

2. Tidak adanya produk spekulatif (gharar) sehingga memiliki ketahanan dan ketangguhan dari direct hit terhadap krisis global bidang keuangan. Jadi secara garis besarnya, bank syariah menciptakan adanya stabilitas terhadap perekonomian nasional dan keuangan.

Adanya sistem bagi hasil dalam bank syariah sehingga memberikan dampak positif, banyak manfaat dan adil kepada masyarakat. Ditinjau dari pemilik dana (deposan), pengelola dana (pihak bank) dan pengusaha (debitur) (Alamsyah, 2012).

Sejak tahun 1988 pada saat pemerintah mengeluarkan Paket Kebijakan Oktober (Pakto) yang berisikan tentang liberalisasi industri terhadap perbankan pada saat inilah adanya gagasan perbankan syariah yang mana para ulama-ulama berusaha agar mendirikan bank tanpa bunga namun tidak adanya perangkat hukum yang bisa untuk dijadikan rujukan terkecuali sistem dalam perbankan 
menetapkan bunganya sebesar 0\% (nol persen). Pada tanggal 19 s/d 22 Agustus 1990 di Cisarua, Bogor adanya lokakarya ulama Indonesia yang merekomendasikan tentang perbankan dan bunga bank. Pada tanggal 22-25 Agustus 1990 diadakan Musyawarah Nasional (Munas) ke- IV oleh Majelis Ulama Indonesia (MUI) di hotel Sahid Jaya, Jakarta pembahasan lebih lanjut dan mendalam tentang pembentukan kelompok-kelompok kerja serta pendirian bank syariah di Indonesia (Nofinawati, 2015).

Bank syariah pertama di Indonesia adalah bank Muamalat sebelum dibentuknya undang-undang No 7 tahun 1992 (Nofinawati, 2015). PT Bank Muamalat Indonesia lahir dari kerja tim perbankan Majelis Ulama Indonesia (MUI), yang mana pada tanggal 1 November 1991 ditanda tanganilah akte pendirian PT Bank Muamalat Indonesia, terkumpul pembelian saham sebesar Rp. 84 miliar.

Kemudian pada tanggal 3 Nopember 1991, acara silaturahmi Presiden di Istana Bogor, disetorlah untuk modal awal sebesar Rp. 106.126.382.000,-. Sejumlah dana modal awal itu berasal dari presiden dan wakil presiden, Supersemar, sepuluh menteri Kabinet Pembangunan V, Yayasan Amal Bakti Muslim Pancasila, Yayasan Dakab, Dharmais, Purna Bhakti Pertiwi, PT Pindad dan PT PAL. Sebagai penopang bank syariah berasal dari yayasan Dana Dakwah Pembangunan. Dari hasil terkumpulnya modal awal tersebut pada tanggal 1 Mei 1992 PT Bank Muamalat Indonesia mulai beroperasi, dengan diperkuat ada nya Undang-undang No 7 tahun 1992 tentang Perbankan yang diperjelas lagi dalam pasal 13 ayat (c) menyatakan bahwa salah satu usaha Bank Perkreditan Rakyat (BPR) menyediakan Pembiayaan bagi nasabah berdasarkan prinsip bagi hasil sesuai dengan ketentuan yang ditetapkan. Setelah dikeluarkan nya UU No 7 tahun 1992 pasal 13 ayat (c) pada tanggal 30 Oktober 1992 dikeluarkan nya Peraturan Pemeruntah (PP) No. 72 tahun 1992 tentang bank berdasarkan prinsip bagi hasil (Nofinawati, 2015).

Setelah berdirinya PT Bank Muamalat Indonesia disertai berdirinnya Bank Perkreditan Rakyat Syariah (BPRS), tetapi kedua lembaga keuangan tersebut belum mapu untuk menjangkau masyarakat islam untuk kalangan bawah maka didirikanlah suatu lembaga mikro syariah yang diberi nama Baitul Maal Wattamwil (BMT). Selama dua tahun PT Bank Muamalat Indonesia beroperasi, 
mensponsori berdirinya Syarikat Takaful Indonesia (STI) dan asuransi Islam serta menjadi salah satu pemegang sahamnya.

Pada tahun 1998 dikeluarkannya UU No. 10 tahun 1998 tentang perubahan UU No. 7 tahun 1992 tentang Perbankan yang mana terdapat perubahan terhadap peluang untuk perkembangan bank syariah, UU No. 10 tahun 1998 menyatakan sistem perbankan syariah dikembangkan dengan tujuan:

1. Kebutuhan pelayanan perbankan untuk masyarakat serta tidak menerapkan sistem bunga. Adanya perbankan syariah yang berjalan dengan bank konvensional berarti mobilitas terhadap dana masyarakat dapat dilakukan dengan lebih luas.

2. Adanya prisip kemitraan sehingga membuka pengembangan usaha. Sistem yang berjalan pada bank syariah merupakan konsep hubungan investor yang harmonis (mutual investor relationship), sedangkan bank konvensional menerapkan konsep hubungan debitur dan kreditur (debitor to creditor relationship).

Dengan berlakunya UU No. 10 tahun 1998 tentang perubahan UU No. 7 tahun 1992 tentang Perbankan makan dikeluarkannya beberapa ketentuan dalam pelaksanaan seperti SK Direksi BI dan Peraturan Bank Indonesia, adanya landasan hukum terhadap pengembangan perbankan syariah di Indonesia berarti memberi kesempatan terhadap perkembangan serta pertumbuhan perbankan syariah dengan medirikan izin mendirikan Kantor Cabang Syariah (KCS) oleh bank konvensional. Dengan kata lain, bank umum dapat menjalankan dua kegiatan usaha, baik secara konvensional maupun berdasarkan prinsip syariah (Nofinawati, 2015).

Pada tanggal 16 Juli 2008, UU No. 21 Tahun 2008 tentang Perbankan Syariah disahkan sehingga menghasilkan landasan hukum perbankan syariah sehingga mendorong pertumbuhan dan perkembangan bank syariah selama 5 tahun terakhir dimana asetnya tumbuh lebih dari $5 \%$ per tahunnya namun secara nasional masih dibawah $5 \%$.

Dalam UU No. 21 Tahun 2008 tentang Perbankan Syariah mengatur secara khusus mengenai perbankan syariah, baik dari sisi kelembagaan maupun dari aspek kegiatan usaha. Ada beberapa lembaga hukum yang baru dalam UU No. 21 Tahun 2008, antara lain yakni menyangkut pemisahan (spin-off) UUS secara sukarela atau wajib dan Komite Perbankan Syariah. Terdapat juga beberapa 
PBI yang diamanahkan oleh UU No. 21 tahun 2008. Adapun PBI yang secara khusus merupakan peraturan pelaksana dari Undang-Undang Nomor 21 Tahun 2008 tentang Perbankan Syariah, ini antara lain:

1. PBI No.10/16/PBI/2008 tentang Perubahan Atas PBI No. 9/19/PBI/2007 tentang Pelaksanaan Prinsip Syariah dalam Kegiatan Penghimpunan Dana dan Penyaluran Dana serta Pelayanan Jasa Bank Syariah.

\begin{tabular}{|c|c|c|}
\hline 2. PBI No.10/17/PBI/2008 & tentang & $\begin{array}{l}\text { Produk Bank Syariah dan Unit Usaha } \\
\text { Syariah. }\end{array}$ \\
\hline 3. PBI No.10/18/PBI/2008 & tentang & $\begin{array}{l}\text { Restrukturisasi } \text { Pembiayaan } \\
\text { Syariah. }\end{array}$ \\
\hline 4. PBI No.10/23/PBI/2008 & tentang & $\begin{array}{l}\text { Perubahan Kedua Atas PBI No. } \\
\text { 6/21/PBI/2004 tentang Giro Wajib } \\
\text { Minimum dalam Rupiah dan Valuta } \\
\text { Asing bagi Bank Umum yang } \\
\text { Melaksanakan Kegiatan Usaha } \\
\text { Berdasarkan Prinsip Syariah. }\end{array}$ \\
\hline 5. PBI No.10/24/PBI/2008 & tentang & $\begin{array}{l}\text { Perubahan Kedua Atas PBI No. } \\
\text { 8/21/PBI/2006 tentang Penilaian } \\
\text { Kualitas Aktiva Bank Umum yang } \\
\text { Melaksanakan Kegiatan Usaha } \\
\text { Berdasarkan Prinsip Syariah. }\end{array}$ \\
\hline $\begin{array}{ll}6 . & \text { PBI } \\
& 10 / 32 / \mathrm{PBI} / 2008\end{array}$ & tentang & Komite Perbankan Syariah \\
\hline PBI No. 11/3/PBI/2009 & tents & Bank Umum Syariah \\
\hline
\end{tabular}
maju dan berkembang. Dampak krisis moneter membawa pengaruh yang positif bagi perbankan syariah karena kalangan masyarakat dan pakar ekonomi tidak cuma memantau melainkan ingin prinsif syariah diterapkan secara maksimal. Perbankan syariah di Indonesia menunjukkan peningkatan yang sangat pesat sehingga akan terus berkembang yang nantinya dapat memperkuat stabilitas perekonomian dan keuangan. Dapat dilihat dari perkembangan dan pertumbuhan bank syariah di Indonesia dari tahun 2000 sampai tahun 2017 perbankan syariah mengalami lonjakan perkembangan yang sangat pesat. Pada tahun 1992 sampai tahun 1999 Bank Umum Syariah di Indonesia hanya ada satu yaitu Bank Muamalat Indonesia (BMI). Tahun 2000 sampai tahun 2003 Bank Umum Syariah bertambah satu lagi yaitu Bank Syariah Mandiri (BSM). Kemudian pada tahun 2004 sampai tahun 2007 Bank Umum Syariah bertambah yaitu Bank Syariah Mega Indonesia (BSMI). Sehingga pada tahun 2008 diklasifikasikan sebagai jenis 
industri yang baru karena memiliki persaingan dan daya tarik yang tinggi, hal ini tampak terlihat tidak hanya dalam kategori bank umum syariah atau BPRS tetapi dalam bentuk UUS (Nofinawati, 2015).

Bank syariah dinilai terbukti mampu menjadi lebih efektif sekaligus mendorong perkembangan dan pertubuhan sehingga adanya daya tarik ditengahtengah masyarakat. Perkembangan dan pertumbuhan bank syariah di Indonesia berkembang dengan pesat walaupun masih relatif baru dibandingkan dengan bank konvensional tetapi sudah menunjukkan prestasi yang baik. Dibawah ini penulis akan memberikan paparan mengenai perkembangan dan pertumbuhan kelembagaan serta kinerja bank syariah di Indonesia mulai tahun 2007 sampai 2017 dalam bentuk tabel berikut ini:

Tabel 1.

Perkembangan dan Pertumbuhan Perbankan Syariah Indonesia Tahun 2007 sampai 2017

\begin{tabular}{llllllllllll} 
Indikator & 2007 & 2008 & 2009 & 2010 & 2011 & 2012 & 2013 & 2014 & 2015 & 2016 & 2017 \\
\hline BUS & 3 & 5 & 6 & 11 & 11 & 11 & 11 & 12 & 12 & 13 & 13 \\
\hline UUS & 26 & 27 & 25 & 23 & 23 & 24 & 23 & 22 & 22 & 21 & 21 \\
\hline BPRS & 114 & 131 & 138 & 150 & 155 & 158 & 163 & 163 & 163 & 166 & 167 \\
\hline $\begin{array}{l}\text { Jaringan } \\
\text { Kantor }\end{array}$ & 782 & 1.024 & 1.223 & 1.763 & 2.101 & 2.663 & 2.990 & 2.910 & 2.747 & 2.654 & 2.610 \\
\hline $\begin{array}{l}\text { Aset } \\
\text { (Miliar }\end{array}$ & 36.5 & 49.55 & 66.09 & 97.51 & 145.4 & 195.0 & 242.2 & 272.3 & 308.98 & 372.88 & 440.304 \\
Rp) & 5 & 0 & 9 & 67 & 18 & 76 & 43 & 9 & 1 & \\
\hline $\begin{array}{l}\text { DPK } \\
\text { (Miliar }\end{array}$ & 28.0 & 36.85 & 52.27 & 76.03 & 115.4 & 147.5 & 183.5 & 217.8 & 231.17 & 279.33 & 334.719 \\
Rp) & 2 & 1 & 6 & 15 & 12 & 34 & 58 & 5 & 5 & \\
\hline $\begin{array}{l}\text { PYD } \\
\text { Miliar }\end{array}$ & 27.9 & 38.19 & 46.88 & 68.18 & 102.6 & 147.5 & 184.1 & 199.3 & 229.54 & 284.25 & 359.070 \\
Rp) & 9 & 6 & 1 & 55 & 05 & 22 & 30 & 4 & 6 & \\
\hline
\end{tabular}

Sumber: Data Statistik Perbankan Syariah OJK (http://www.ojk.go.id), data diolah

Keterangan:
BUS : Bank Umum Syariah
USS : Unit Usaha Syariah
BPRS : Bank Pembiayaan Rakyat Syariah
DPK : Dana Pihak Ketiga
PYD : Pembiayaan Yang Diberikan 


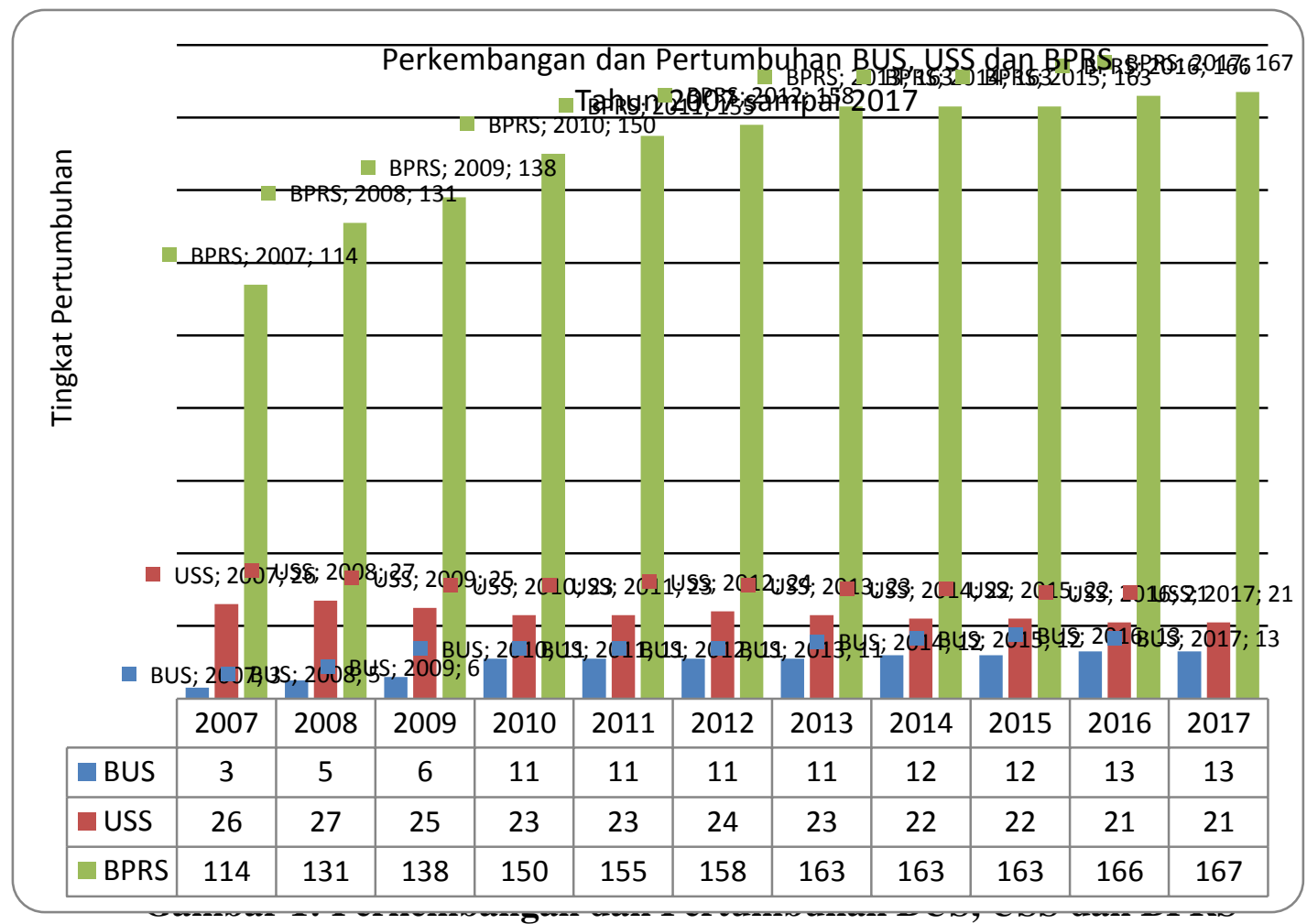

Berdasarkan diagram di atas, dapat diketahui dan dilihat bahwa dari sektor kelembagaannya apabila dilihat dari BUS (Bank Umum Syariah) mulai tahun 2007 sampai 2017 pertumbuhan perbankan syariah mengalami peningkatan walaupun peningkatannya tidak terlalu tinggi. Pada tahun 2007 jumlah BUS hanya 3, tahun 2008 menjadi 5 atau 66,6\%, tahun 2009 berjumlah 6 atau 20\%, kenaikan tinggi tahun 2010 dan tetap stabil sampai 2013 berjumlah 11 atau $83,4 \%$, tahun 2014 sampai 2015 naik menjadi 12 atau 9,03\% dan yang terakhir tahun 2016 sampai 2017 bertambah lagi menjadi 13 atau 8,3\%.

Sedangkan USS (Unit Usaha Syariah) mengalami fluktuasi, dimana tahun 2007 mengalami kenaikan dari tahun sebelumnya yaitu berjumlah 26 atau 30\%, jumlah tertinggi pada tahun 2008 yaitu 27 atau 3,84\%, pada tahun 2009 menurun menjadi 25 atau 7,4\%, pada tahun 2010 dan 2011 mengalami penurunan kembali dengan jumlah 23 atau 8\%, kembali naik pada tahun 2012 menjadi 24 atau 4,34\%, tetapi pada tahun 2013 turun menjadi 23 atau 4,16\%, pada tahun 2014 dan 2015 mengalami penurunan kembali menjadi 22 atau 4,34\% dan terakhir jumlah USS turun kembali pada tahun 2016 dan 2017 menjadi 21 atau 4,54\% .

Jumlah BPRS (Bank Pembiayaan Rakyat Syariah) mulai dari tahun 2007 sampai tahun 2017 mengalami peningkatan yang sangat baik, pada tahun 2007 BPRS berjumlah 114 pertumbuhan naik dengan tingkat rata-rata $8,57 \%$ dari tahun 
sebelumya. Pada tahun 2008 BPRS mengalami kenaikan menjadi 131 atau 14,91\%. Pada tahun 2009 pertumbuhan BPRS mengalami kenaikan 138 atau 5,34\%. Pada tahun tahun 2010 pertumbuhan BPRS naik menjadi 150 atau 8,69\%. Pada tahun 2011 pertumbuhan BPRS naik menjadi 155 atau 3,33\%. Pada tahun 2012 pertumbuhan BPRS naik sebanyak 158 atau 1,93\%. Pertumbuhan BPRS naik sebanyak 163 dari tahun 2013, 2014 dan 2015 atau 3,16\%. Pada tahun 2016 pertumbuhan BPRS naik sebanyak 166 atau 1,84\%. Dan yang terakhir pada tahun 2017 pertumbuhan BPRS naik sebanyak 167 atau 0,60\%.

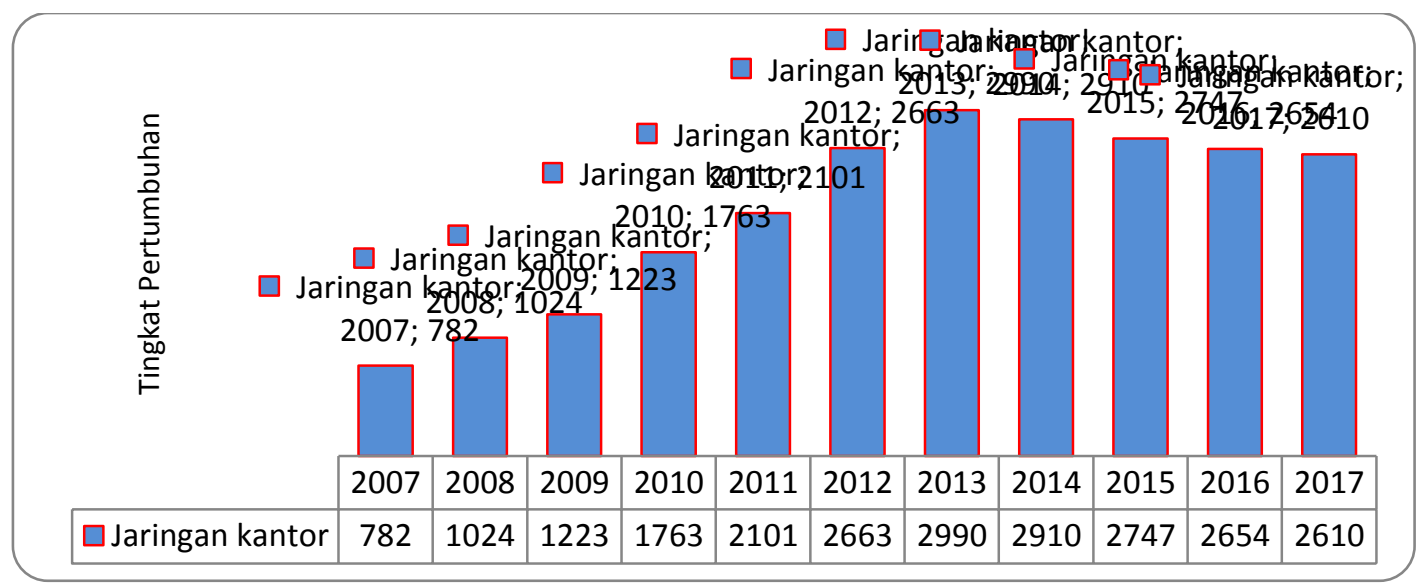

Gambar 2: Perkembangan dan Pertumbuhan Jaringan Kantor tahun 2007 sampai dengan 2017

Berdasarkan diagram di atas, dapat diketahui dan dilihat bahwa pertumbuhan jumlah jaringan kantor perbankan syariah mulai tahun 2007 sampai 2017 berfluktuasi. Pada tahun 2007 jumlah jaringan kantor perbankan syariah sebanyak 782 naik sebesar 22,76\% dari tahun sebelumnya. Pada tahun 2008 jumlah jaringan kantor perbankan syariah naik menjadi 1024 atau 30,9\%. Pada tahun 2009 jumlah jaringan kantor perbankan syariah naik menjadi 1223 atau 19,43\%. Pada tahun 2010 jumlah jaringan kantor perbankan syariah naik menjadi 1763 atau 44,15\%. Pada tahun 2011 jumlah jaringan kantor perbankan syariah naik menjadi 2101 atau 19,17\%. Pada tahun 2012 jumlah jaringan kantor perbankan syariah naik menjadi 2663 atau 26,74\%. Pada tahun 2013 jumlah jaringan kantor perbankan syariah naik menjadi 2990 atau 12,27\%. Pada tahun 2014 jumlah jaringan kantor perbankan syariah mengalami penurunan menjadi 2910 atau 2,7\%. Pada tahun 2015 jumlah jaringan kantor perbankan syariah mengalami penurunan menjadi 2747 atau 5,9\%. Pada tahun 2016 jumlah jaringan kantor perbankan syariah mengalami penurunan menjadi 2654 atau 3,5\%. Pada 
tahun 2017 jumlah jaringan kantor perbankan syariah mengalami penurunan menjadi 2610 atau $1,65 \%$.

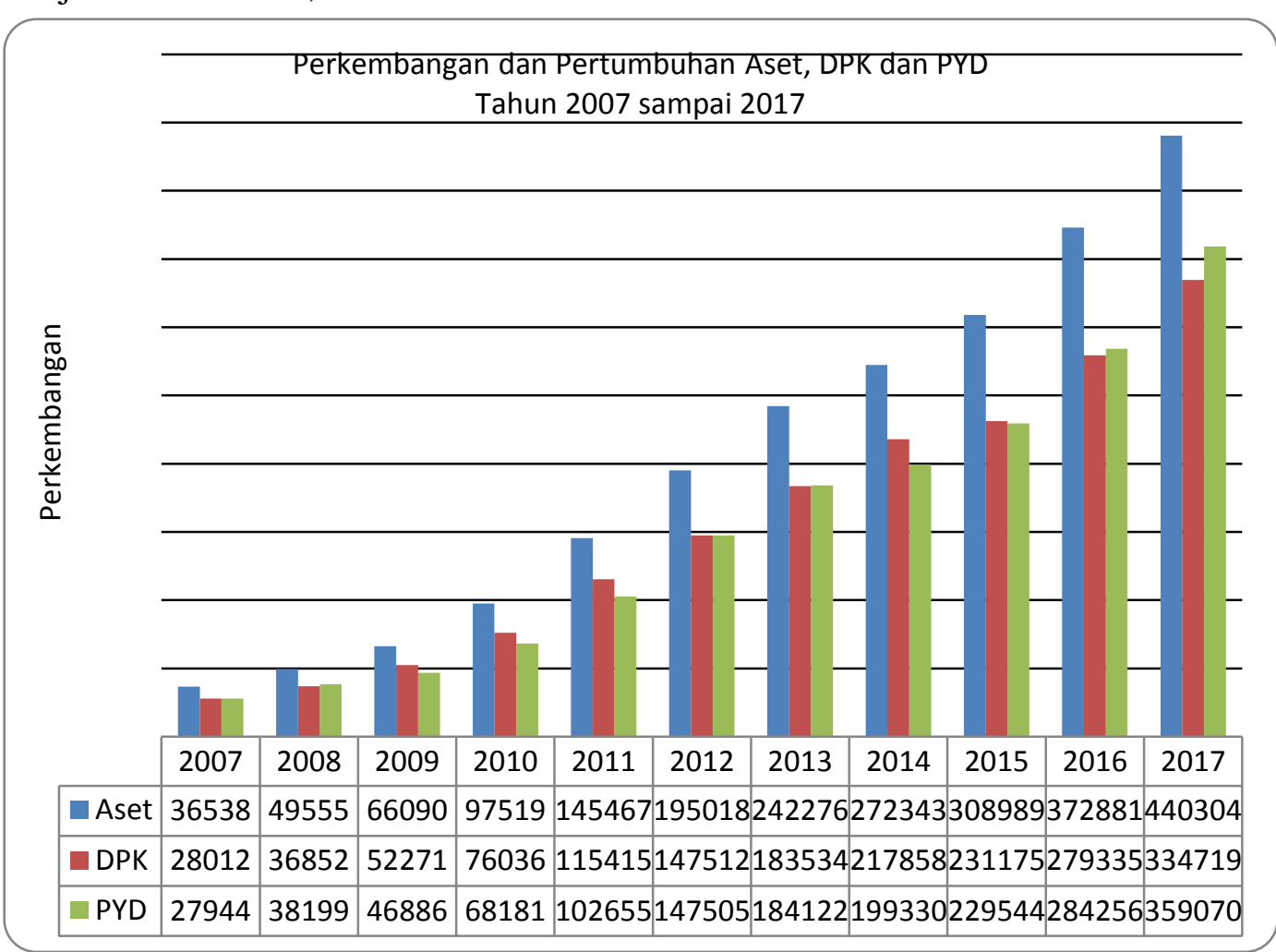

Gambar 3: Perkembangan dan Pertumbuhan Aset, DPK dan PYD

Apabila ditinjau dari penghimpunan dan penyaluran dana, perbankan syariah di Indonesia selalu memperlihatkan kinerja yang terus meningkat. Dapat dilihat dari gambar 3 dan data-data statistik perbankan syariah yang di tampilkan pada Otoritas Jasa Keuangan (OJK). Pertumbuhan dan perkembangan jumlah aset, DPK (Dana Pihak Ketiga), dan jumlah PYD (Pembiayaan yang Disalurkan) selalu meningkat dari tahun 2007 sampai 2017. Aset pada tahun 2007 mengalami pertumbuhan sebesar 36.538 atau 36,73\% dari tahun sebelumnya. Pada tahun 2008 mengalami peningkatan menjadi 49.555 atau 35,62\%. Pada tahun 2009 aset mengalami peningkatan sebesar 66.090 atau 33,39\%. Pada tahun 2010 aset mengalami peningkatan sebesar 97.519 atau 47,55\%. Pada tahun 2011 aset mengalami peningkatan sebesar 145.467 atau 49,16\%. Pada tahun 2012 aset mengalami peningkatan sebesar 195.018 atau 34,06\%. Pada tahun 2013 aset mengalami peningkatan sebesar 242.276 atau 24,23\%. Pada tahun 2014 aset mengalami peningkatan sebesar 272.343 atau 12,41\%. Pada tahun 2015 aset mengalami peningkatan sebesar 308.989 atau 13,45\%. Pada tahun 2016 aset mengalami peningkatan sebesar 372.881 atau 20,67\%. Pada tahun 2017 aset mengalami peningkatan sebesar 440.304 atau $18,08 \%$. 
DPK (Dana Pihak Ketiga) pada tahun 2007 mengalami pertumbuhan sebesar 28.012 atau 35,50\% dari tahun sebelumnya. Pada tahun 2008 DPK mengalami peningkatan menjadi 36.852 atau 31,55\%. Pada tahun 2009 DPK mengalami peningkatan menjadi 52.271 atau 41,84\%. Pada tahun 2010 DPK mengalami peningkatan menjadi 76.036 atau 45,46\%. Pada tahun 2011 DPK mengalami peningkatan menjadi 115.415 atau 51,78\%. Pada tahun 2012 DPK mengalami peningkatan menjadi 147.512 atau 27,81\%. Pada tahun 2013 DPK mengalami peningkatan menjadi 183.534 atau 24,41\%. Pada tahun 2014 DPK mengalami peningkatan menjadi 217.858 atau 18,70\%. Pada tahun 2015 DPK mengalami peningkatan menjadi 231.175 atau 6,11\%. Pada tahun 2016 DPK mengalami peningkatan menjadi 279.335 atau 20,83\%. Pada tahun 2017 DPK mengalami peningkatan menjadi 334.719 atau $19,82 \%$.

Sementara untuk PYD (Pembiayaan yang Disalurkan) pada tahun 2007 mengalami pertumbuhan sebesar 27.944 atau 36,67\% dari tahun sebelumnya. Pada tahun 2008 PYD mengalami peningkatan sebesar 38.199 atau 36,7\%. Pada tahun 2009 PYD mengalami peningkatan menjadi 46.886 atau 22,74\%. Pada tahun 2010 PYD mengalami peningkatan menjadi 68.181 atau 45,41\%. Pada tahun 2011 PYD mengalami peningkatan menjadi 102.655 atau 50,56\%. Pada tahun 2012 PYD mengalami peningkatan menjadi 147.505 atau 43,69\%. Pada tahun 2013 PYD mengalami peningkatan menjadi 184.122 atau 24,82\%. Pada tahun 2014 PYD mengalami peningkatan menjadi 199.330 atau 8,26\%. Pada tahun 2015 PYD mengalami peningkatan menjadi 229.544 atau 15,15\%. Pada tahun 2016 PYD mengalami peningkatan menjadi 284.256 atau 23,83\%. Pada tahun 2017 PYD mengalami peningkatan menjadi 359.070 atau 26,31\%.

\section{Daftar Pustaka}

Alamsyah, Halim. 2012. "Perkembangan Dan Prospek Perbankan Syariah Indonesia: Tantangan Dalam Menyongsong MEA 2015." Milad ke-8 Ikatan Ahli Ekonomi Islam (IAEI) (April 2012): 1-8.

Diana Yumanita, Ascarya. 2010. 14 pengertian Bank Syariah journal Bank Syariah: Gambaran Umum PUSAT.

Fasa, Muhammad Iqbal. 2013. "Tantangan Dan Strategi Perkembangan Perbankan Syariah Di Indonesia.” Jurnal Ekonomi Islam VII(2): 19-40.

Marimin, Agus, Abdul Haris Romdhoni, and Tira Nur Fitria. 2015. 
"Perkembangan Bank Syariah Di Indonesia." Jurnal Ilmiah Ekonomi Islam 1(2): 75-87.

Munawir, H. 2005. "Perencanaan Strategi Pengembangan Bank Syariah Di Indonesia." Jurnal Ilmiah Teknik Industri 4(1): 41-48.

Nofinawati. 2015. "Perkembangan Perbankan Syariah Di Indonesia." Jurnal JURIS 14(2): 168-83.

Sari, Mutiara dwi, Zakaria Bahari, and Zahri Hamat. 2013. "Perkembangan Perbankan Syariah Di Indonesia : Suatu Tinjauan.” Jurnal Aplikasi Bisnis 3(2): $120-38$.

Suhendro, Dedi. 2016. "Pengaruh Kualitas Sistem, Kualitas Informasi, Kualitas Pelayanan Dan Ekspektasi Kinerja Terhadap Kepuasan Pengguna Dalam Penerapan Sistem Teknologi Informasi Pada Koperasi Di Kota Pematang Siantar.” JURASIK (Jurnal Riset Sistem Informasi \& Teknik Informatika) 1(1): 33-40.

—. 2018. "Analisis Perbandingan Kinerja Keuangan Bank Umum Syariah VS Bank Umum Konvensional Di Indonesia Dengan Menggunakan Rasio Keuangan." Jurnal Masharif al-Syariah: Jurnal Ekonomi dan Perbankan Syariah 3(1).

Syukron, Ali. 2013. "Dinamika Perkembangan Perbankan Syariah Di Indonesia." Jurnal Ekonomi dan Hukum Islam 3(2): 28-53.

Undang-Undang Republik Indonesia Nomor 7 Tahun 1992 Tentang Perbankan

Undang-Undang Perbankan dengan UU No. 10 Tahun 31998 Tentang Perubahan Atas Undang-Undang Nomor 7 Tahun 1992 Tentang Perbankan.

Undang-Undang Nomor 21 Tahun 2008 Tentang Perbankan Syariah

https://ojk.go.id/id/Default.aspx 